Portland State University

PDXScholar

\title{
Isolation of a Ubiquitous Obligate Thermoacidophilic Archaeon From Deep-Sea Hydrothermal Vents
}

\author{
Anna-Louise Reysenbach \\ Portland State University, reysenbacha@pdx.edu \\ Yitai Liu \\ Portland State University \\ Amy B. Banta \\ Portland State University \\ Terry J. Beveridge \\ University of Guelph \\ Julie D. Kirshtein \\ US Geological Survey
}

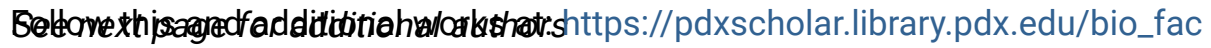

Part of the Archaea Commons, and the Biochemistry Commons

Let us know how access to this document benefits you.

\section{Citation Details}

Reysenbach, Anna-Louise; Liu, Yitai; Banta, Amy B.; Beveridge, Terry J.; Kirshtein, Julie D.; Schouten, Stefan; Tivey, Margaret K.; Von Damm, Karen L.; and Voytek, Mary A., "Isolation of a Ubiquitous Obligate Thermoacidophilic Archaeon From Deep-Sea Hydrothermal Vents" (2006). Biology Faculty Publications and Presentations. 54.

https://pdxscholar.library.pdx.edu/bio_fac/54

This Post-Print is brought to you for free and open access. It has been accepted for inclusion in Biology Faculty Publications and Presentations by an authorized administrator of PDXScholar. Please contact us if we can make this document more accessible: pdxscholar@pdx.edu. 


\section{Authors}

Anna-Louise Reysenbach, Yitai Liu, Amy B. Banta, Terry J. Beveridge, Julie D. Kirshtein, Stefan Schouten, Margaret K. Tivey, Karen L. Von Damm, and Mary A. Voytek 


\section{Isolation of a ubiquitous obligate thermoacidophilic archaeon from deep-sea hydrothermal vents}

Anna-Louise Reysenbach ${ }^{1}$, Yitai Liu ${ }^{1}$, Amy B. Banta $^{1}$, Terry J. Beveridge ${ }^{2}$, Julie D.

Kirshtein ${ }^{3}$, Stefan Schouten ${ }^{4}$, Margaret K. Tivey ${ }^{5}$, Karen Von Damm ${ }^{6} \&$ Mary A.

Voytek $^{3}$

${ }^{1}$ Dept of Biology, Portland State University, Portland, OR 97201, USA.

${ }^{2}$ Dept. of Molecular \& Cellular Biology, University of Guelph, Guelph, Canada.

${ }^{3}$ USGS, MS 430, 12201 Sunrise Valley Drive, Reston, VA 20192, USA.

${ }^{4}$ Department of Marine Biogeochemistry \& Toxicology, Royal Netherlands Institute for Sea Research, 1790 AB Den Burg, Texel, The Netherlands.

${ }^{5}$ Dept of Marine Chemistry and Geochemistry, WHOI, Woods Hole MA 02543, USA.

6Complex Systems Research Center, EOS, University of New Hampshire, 366 Morse Hall, 39 College Road, Durham, New Hampshire. 03824-3525, USA.

Deep-sea hydrothermal vents play an important role in global biogeochemical cycles, providing biological oases at the seafloor that are supported by the thermal and chemical flux from the Earth's interior. As hot, acidic and reduced hydrothermal fluids mix with cold, alkaline and oxygenated seawater, minerals precipitate to form porous sulphide-sulphate deposits. These structures provide microhabitats for a diversity of prokaryotes that exploit the geochemical and physical gradients in this dynamic ecosystem ${ }^{1}$. It has been proposed that fluid pH 
in the actively-venting sulphide structures is generally low $(\mathrm{pH}<4.5)^{2}$ yet no extreme thermoacidophile has been isolated from vent deposits. Cultureindependent surveys based on rRNA genes from deep-sea hydrothermal deposits have identified a widespread euryarchaeotal lineage, DHVE2 ${ }^{3-6}$. Despite DHVE2's ubiquity and apparent deep-sea endemism, cultivation of this group has been unsuccessful and thus its metabolism remains a mystery. Here we report the isolation and cultivation of a member of the DHVE2 group, which is an obligate thermoacidophilic sulphur or iron reducing heterotroph capable of growing from pH 3.3 to 5.8 and between 55 to $75^{\circ} \mathrm{C}$. In addition, we demonstrate that this isolate constitutes up to $15 \%$ of the archaeal population, providing the first evidence that thermoacidophiles may be key players in the sulphur and iron cycling at deep-sea vents.

Since their discovery in 1977, deep-sea hydrothermal vents have provided one of the only environments on Earth for searching for the upper temperature limits of life; these ecosystems may represent models for both the origin of life on Earth and exploration of life on other planets. This ecosystem, fuelled largely by geochemical energy, hosts many invertebrates new to science, and they often thrive because of their endosymbiotic bacterial partners. Likewise, these deep-sea oases have provided a vast array of newly described free-living microbes, many associated with the actively forming porous deep-sea vent deposits such as 'chimneys'. Here, the contrasting geochemistry of hydrothermal fluids and seawater, the mineralogy of porous substrates, and microbial activity are tightly coupled. The steep chemical and thermal gradients within the walls of the deposits provide a wide range of microhabitats for microorganisms ${ }^{7}$. For example, calculations of transport across chimney walls ${ }^{2}$ showed that, the $\mathrm{pH}$ of fluids $\left(\mathrm{at}<120^{\circ} \mathrm{C}\right.$ ) within pores of chimney's should be very low ( $\mathrm{pH}$ $<3$ ) if only diffusion is occurring. 
If some advection of seawater into the chimney occurs, the porewater $\mathrm{pH}$ at 50 to $80^{\circ} \mathrm{C}$ should still be low (around $\mathrm{pH} 4$ to 6 ); with advection of vent fluid outward, $\mathrm{pH}$ at 50 to $80^{\circ} \mathrm{C}$ should range from $<3$ to 6 for low rates of flow, or 3 to 4.5 (similar to that of the vent fluid measured at $25^{\circ} \mathrm{C}$ ) for rapid rates of flow ${ }^{2,8}$. This agrees well with an in situ measurement of $\mathrm{pH}$ made at the exterior of a chimney wall at $13^{\circ} \mathrm{N}$ on the EPR, beneath a colony of Alvinella pompejana; the $\mathrm{pH}$ was 4.1 at a temperature of $120^{\circ} \mathrm{C}^{9}$. In addition, localized acidity is produced chemically as minerals such as pyrite and chalcopyrite form, namely, $\mathrm{Fe}^{2+}+2 \mathrm{H}_{2} \mathrm{~S}=\mathrm{FeS}_{2}+\mathrm{H}_{2}+2 \mathrm{H}^{+}$and $\mathrm{Cu}^{+}+\mathrm{Fe}^{2+}+2 \mathrm{H}_{2} \mathrm{~S}=$ $\mathrm{CuFeS}_{2}+0.5 \mathrm{H}_{2}(\mathrm{aq})+3 \mathrm{H}^{+}$. It is therefore surprising that all thermophiles thus far isolated from deep-sea vents, are neutrophiles, or slightly acidophilic ${ }^{10}$ and at best acidotolerant ${ }^{11}$, and grow very poorly or not at all at the predicted low $\mathrm{pH}$ conditions from which they were isolated. For example, Thermococcus, perhaps the most frequently cultivated thermophile from deep-sea vents, grows best around $\mathrm{pH} 6.5$, with the majority of species unable to grow below pH 5.5 and only some species can grow very poorly at about $\mathrm{pH} 4^{12}$.

Culture-dependent and culture-independent approaches have exposed a vast

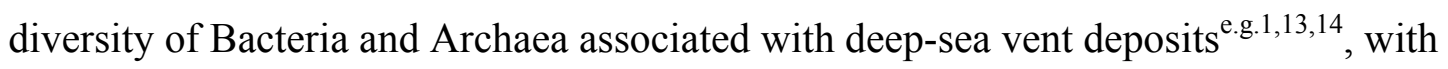
the Bacteria being dominated by many novel branches of the Epsilonproteobacteria ${ }^{15}$. However, although numerous Archaea have been isolated from these deposits, few isolates are found in environmental 16S rRNA gene clone libraries and most environmental clones have no representatives in culture. In particular, one lineage is widespread at deep-sea vents and is frequently associated with actively venting sulphide deposits. The "deep-sea hydrothermal vent euryarchaeotic" lineage DHVE2, is often found in clone libraries ${ }^{\text {e.g.3-6,14,16 }}$ and has been reported as the most dominant clone type in some archaeal clone libraries ${ }^{6}$ (Supplementary Tables 1, 2). 
Using a specific primer set for the DHVE2 16S rRNA gene (Supplementary Methods), we screened 63 samples from multiple vent sites along two ridge systems (the East Pacific Rise, EPR, from $9^{\circ} 16.8^{\prime} \mathrm{N} 104^{\circ} 13^{\prime} \mathrm{W}$ to $20^{\circ} 50^{\prime} \mathrm{N} 109^{\circ} 07^{\prime} \mathrm{W}$ and the Eastern Lau Spreading Center, ELSC, from $20^{\circ} 3.2^{\prime} \mathrm{S} 176^{\circ} 8.0^{\prime} \mathrm{W}$ to $22^{\circ} 10.8^{\prime} \mathrm{S}$ $176^{\circ} 36.1^{\prime} \mathrm{W}$ ) during 3 different research cruises (Supplementary Table 2, Supplementary Fig. S1). The DHVE2 were identified in 36 samples and represented up to 10 and $15 \%$ of the archaeal population at EPR and ELSC, respectively (as determined by quantitative PCR; Table 1). Generally, the occurrence of DHVE2 appeared to be associated with the fine-grained white elemental sulphur, $\mathrm{S}_{8}$, (identified in three different samples by X-ray diffraction, Supplementary Methods) or iron oxyhydroxide (X-ray amorphous - identified based on orange color and texture, Supplementary Table 3) deposits that often coat the outside of mature actively venting sulphide deposits (Supplementary Fig. S2). Additionally, due to the high guanine and cytosine content of the 16S rRNA sequence and its occasional co-occurrence with thermophiles such as Thermococcus, it has been suggested that the DHVE2 are thermophiles, perhaps heterotrophs whose growth may be stimulated by sulphur ${ }^{1,16}$. A DHVE2 genome fragment from a metagenome library contained a thermostable DNA polymerase, which was further suggestive of the thermophilic nature of this lineage ${ }^{17}$. However, all attempts to culture this group using standard media and conditions to select for sulphate reducers, methanogens or fermenters at 60,80 and $90^{\circ} \mathrm{C}$ and around $\mathrm{pH} 6.5$ have been unsuccessful ${ }^{5}$.

Based on the predictions that conditions within many sulphide deposits should be acidic, and due to the presence of novel sequences most closely related to the acidophiles, Thermoplasma, Picrophilus and Ferroplasma (Fig. 1, sequence LART667E06) and the presence of the DHVE2 group from two samples obtained from the Mariner deep-sea vent along the ELSC $\left(22^{\circ} 10.8^{\prime} \mathrm{S}, 176^{\circ} 36.1^{\prime} \mathrm{W}-\right.$ depth of vent field $\sim 1920 \mathrm{~m}^{18}$ ), we enriched for heterotrophic thermoacidophiles (pH 4.5) using trypticase 
peptone, yeast extract and elemental sulphur. After a week, two cultures (designated strains T449 and T469), were purified by three serial dilutions. Comparative sequence analysis of the 16S rRNA gene of strains T449 and T469 placed these isolates within the DHVE2. The group forms a monophyletic clade and isolates are closely related (about 95-97\% similar) to cloned 16S rRNA gene sequences obtained from deep-sea vents and a sequence obtained from methane hydrate-bearing marine sediments at about 200 mbsf from the Cascadia Margin ${ }^{19}$ (Supplementary Table 1). The new isolates are only $83 \%$ similar in $16 \mathrm{~S}$ rRNA sequence to their closest relative in culture,

Thermoplasma volcanium, an isolate from shallow marine vents and solfataras ${ }^{20}$ which grows best at $\mathrm{pH} 2.0$ and $60^{\circ} \mathrm{C}$ (Table 2). Additional thermoacidophilic enrichments of DHVE2 were obtained from two sites along the ELSC (Kilo Moana, 20 $3.2^{\prime} \mathrm{S} 176^{\circ}$ $8.0^{\prime} \mathrm{W}, \sim 2620 \mathrm{~m}$ and Tow Cam, $20^{\circ} 19.1^{\prime} \mathrm{S} 176^{\circ} 8.2^{\prime} \mathrm{W}$, about $2720 \mathrm{~m}^{21}$ ) and 5 sites along the EPR (at $\left.9^{\circ} 17^{\prime} \mathrm{N}, 9^{\circ} 33^{\prime} \mathrm{N}, 9^{\circ} 46^{\prime} \mathrm{N}, 9^{\circ} 47 \mathrm{~N}^{\prime}, 9^{\circ} 50^{\prime} \mathrm{N}\right)$. One strain from the Mariner vent site, T469, was further characterized and its purity was confirmed by repeated sequencing of the $16 \mathrm{~S}$ rRNA gene.

Strain T469 is the first obligate thermoacidophile to be reported from deep-sea vents and the first cultivated member of the DHVE2 group. The organism grows between $\mathrm{pH} 3.3$ and 5.8, growing best between $\mathrm{pH}$ 4.2-4.8 (Supplementary Fig. S3) at $70^{\circ} \mathrm{C}$ and to a maximum cell density of about $4-6 \times 10^{8}$ cells $/ \mathrm{ml}$. The isolate does not grow above $77^{\circ} \mathrm{C}$ or below $50^{\circ} \mathrm{C}$, but like Thermococcales and Thermotogales it is an obligate anaerobe requiring elemental sulphur (or ferric iron), $\mathrm{NaCl}$ (optimum 2.5-3.5\% $\mathrm{w} / \mathrm{v}$ ) and complex organics such as trypticase peptone, casein and yeast extract for growth (Supplementary Methods, Table 2). Chemical analyses showed that its membrane lipids are predominantly composed of glycerol dibiphytanyl glycerol tetraethers containing 0-4 cyclopentane rings. These membrane lipids have also been detected in the closest cultured relatives Ferroplasma and Thermoplasma and are thought to be unique to thermoacidophilic Crenarchaeota and Euryarchaeota ${ }^{22}$. 
The cells are pleiomorphic to spherical, about $0.6-1 \mu \mathrm{m}$ in diameter and are motile with a single flagellum (Fig. 2a, b). Some flagella have their proximal end encased in an unusual complex periodic sheath (Fig. 2c). Like many other Archaea (e.g.

Methanococcus and Sulfolobus), they are enveloped by a plasma membrane and a single S-layer (Fig. 2a, e). The S-layer, similar to that of Picrophilus oshimae ${ }^{23}$, is thick $(\sim 40 \mathrm{~nm})$, with a presumed tetragonal $(p 4)$ lattice and resembles a delicate bridal veil bordering the cells (Fig. 2a). Although S-layers are quasi-crystalline this S-layer bends into small highly curved structures (Fig. 2d, vesicles). These vesicles bud from the cell partitioning small quantities of cytoplasm that could then anneal to adjacent cells. This is a process that is common amongst their Gram-negative bacterial counterparts ${ }^{24}$. The ability of DHVE2's S-layer to bend into such high curvature structures as these vesicles, suggests that the bonding forces between S-layer subunits are weak or transient. This is unusual $^{25}$, especially since this S-layer is the sole cell wall structure.

As this organism is the first isolate in the DHVE2 clade, representing a new Order within the phylum Euryarchaeaota, we propose the following candidate status of this taxon, 'Aciduliprofundum boonei', gen. nov. sp. nov.

Etymology. A.ci.du.li.pro.fun'dum. L. adj. acidulus, a little sour, acidulous; L. adj. profundus, deep; N.L. neut. n. Aciduliprofundum, a bacterium isolated from acidic deep-sea vents. bo.o.ne'i. N.L. gen. n. boonei, of Boone, named in honor of David Boone for his contributions to the study of archaeal diversity.

Diagnosis. Anaerobic heterotrophic sulphur and iron reducing thermoacidophile belonging to the kingdom Euryarchaeota. Cells are pleiomorphic to spherical about 0.6$1 \mu \mathrm{m}$ in diameter, with a single flagellum and an S-layer. Grows best at $70^{\circ} \mathrm{C}$ and $\mathrm{pH}$ 4.2-4.8. From actively venting deep-sea vent deposits, first isolated from deep-sea vents at $22^{\circ} 10.8^{\prime} \mathrm{S}, 176^{\circ} 36.1^{\prime} \mathrm{W}$ (Mariner vent field). 
The successful cultivation of this first thermoacidophile from deep-sea vents points to the importance of the role that culture-independent approaches have played in exposing the vastness and ecological significance of the diversity of microbes, but also to the integrative approach where geochemical modelling has predicted the environmental conditions in which this diversity thrives. Furthermore, this new archaeon shares an overlapping niche with other fast growing thermophilic heterotrophs such as Thermococcus. It is likely that under most enrichment conditions of higher $\mathrm{pH}$, Thermococcus would rapidly outcompete the DHVE2, and this prevented our successful isolation of this novel lineage in the past. The DHVE2 are often found co-occurring with lineages such as the Epsilonproteobaceria (based on 16S rRNA gene data not shown). These bacteria are likely autotrophic sulphide/sulphur or hydrogen oxidizers ${ }^{15}$ that could create a localized anaerobic environment (and also biologically lower the local $\mathrm{pH}$ ), providing a microniche for anaerobic acidophiles. Additionally, due to the DHVE2 association with dense biofilms that form amongst iron oxides and elemental sulphur, it is possible that these communities provide both the oxidized substrates and the complex organics to support the observed metabolism of this new archaeon.

With this first confirmation of extreme thermoacidophiles from deep-sea vents, it is likely that this physiological group plays a central role in the biogeochemistry and mineralogy at deep-sea vents. It is thus possible that the numerous lineages that have been identified from similar environments using culture-independent approaches, may be acidophiles, or inhabit some microhabitat yet to be identified. Such novel isolates will not only expand our understanding of the role these organisms play in the hydrothermal vent environment, but also provide clues to the biosignatures that remain in the ancient hydrothermal rock record. 


\section{METHODS}

Full details are given in the Supplementary Methods

Sampling sites. Actively venting sulphide samples were collected using the $D S R V$ Alvin or DSROV Jason II from the EPR or ELSC, respectively. Once shipboard, subsamples where the DHVE2 were detected were taken by using sterile spatulas and removing the about 1-3 mm deep superficial sulfur or iron crusts. Samples were stored anaerobically in serum vials and at $4{ }^{\circ} \mathrm{C}$ as rock slurries or frozen immediately for DNA extractions.

Enrichment cultivation and isolation. Enrichment cultures were started several months later in the land-based laboratory at Portland State University. Initial enrichments were incubated at $70^{\circ} \mathrm{C}$ in anaerobic marine media (Supplementary Methods). Growth was monitored by cell counts in triplicate cultures, and repeated at least twice. A suite of carbon source sugars and proteinaceous compounds were tested at $0.1-0.5 \%$ (w/v, final concentration, Supplementary Methods) as alternative carbon sources in media amended with vitamins or $0.01 \%$ yeast extract.

Real-time PCR (qPCR). Samples were analyzed for DHVE2 abundance and total archaeal abundance by real-time PCR (Supplementary Methods).

Phylogenetic analysis of $16 \mathrm{~S}$ rRNA sequences. 16S rRNA gene sequences were amplified by PCR (Supplementary Methods) and manually aligned based on secondary structure constraints in the ARB software package ${ }^{26}$. Phylogenetic relationships were determined using evolutionary distance and maximum likelihood analysis. Phylogenetic trees were constructed using 1356 homologous nucleotides with the fastDNAml program $^{27}$ employing an optimized $\mathrm{T}$ transition/transversion ratio of 1.52 and the global branch rearrangements option. Confidence of tree topologies were estimated by performing 100 bootstrap replicates using fastDNAml. 
Membrane lipid analysis. Membrane lipids were extracted (Supplementary

Methods)and analysed by high performance liquid chromatography/atmospheric pressure chemical ionisation/mass spectrometry ${ }^{28}$.

Transmission electron microscopy. Both negatively-stained cells and stained thin sections (Supplementary methods) were viewed with a Philips CM10 operating under standard conditions at $100 \mathrm{kV}$. 
1. Reysenbach, A. L. \& Shock, E.L. Merging genomes with geochemistry in hydrothermal ecosystems. Science 296, 1077-1082 (2002).

2. Tivey, M. K. in Subseafloor Biosphere at Mid-Ocean Ridges, Geophysical Monograph Series, (ed. Wilcock, W., Cary, C., DeLong, E., Kelley, D., Baross, J.) 137152 (American Geophysical Union, Washington, DC, 2004).

3. Takai, K. \& Horikoshi, K. Genetic diversity of archaea in deep-sea hydrothermal vent environments. Genetics 152, 1285-1297 (1999).

4. Reysenbach, A.-L., Longnecker, K. \& Kirshtein, J. Novel bacterial and archaeal lineages from an in situ growth chamber deployed at a Mid-Atlantic Ridge hydrothermal vent. Appl. Environ. Microbiol 66, 3798-3806 (2000).

5. Nercessian, O., Reysenbach, A.-L., Prieur, D. \& Jeanthon, C. Compositional changes in archaeal communities associated with deep-sea hydrothermal vent samples from the East Pacific Rise (13 N). Environ. Microbiol 5, 492-502 (2003).

6. Hoek, J., Banta, A. B., Hubler, R. F. \& Reysenbach, A.-L. Microbial diversity of a deep-sea hydrothermal vent biofilm from Edmond vent field on the Central Indian Ridge. Geobiology 1, 119-127 (2003).

7. McCollom, T. M., \& Shock, E.L. Geochemical constraints on chemolithoautotrophic metabolism by microorganisms in seafloor hydrothermal systems. Geochim. Cosmochim. Acta 61, 4375-4391 (1997).

8. Von Damm, K. L. in Physical, Chemical, Biological, and Geological Interactions within Seafloor Hydrothermal Systems (eds. Humphris, S., Lupton, J., Mullineaux, L. \& Zierenberg, R.) 222-247 (American Geophysical Union, Washington, DC, 1995). 
9. Le Bris, N., Zbinden, M. \& Gaill, F. Processes controlling the physicochemical micro-environments associated with Pompeii worms. Deep Sea Research 52, 10711083, (2005).

10. Takai, K. et al. Lebetimonas acidiphila gen. nov., sp. nov., a novel thermophilic, acidophilic, hydrogen-oxidizing chemolithoautotroph within the 'Epsilonproteobacteria', isolated from a deep-sea hydrothermal fumarole in the Mariana Arc. Int.J. Syst. Evol. Microbiol 55, 183-189 (2005).

11. Prokofeva, M. et al. Cultivated anaerobic acidophilic/acidotolerant thermophiles from terrestrial and deep-sea hydrothermal habitats. Extremophiles 9, 437-448 (2005).

12. Kobayashi, T. in Bergeys Manual of Systematic Bacteriology (ed. Boone, D. R., Castenholz, R. W., Garrity, G. M.) 342-346 (Springer-Verlag, New York, 2001).

13. Schrenk, M. O., Kelley, D. S., Delaney, J. R. \& Baross, J. A. Incidence and diversity of microorganisms within the walls of an active deep-sea sulfide chimney. Appl. Environ. Microbiol 69, 3580-3592 (2003).

14. Nakagawa, T. et al. Geomicrobiological exploration and characterization of a novel deep-sea hydrothermal system at the TOTO caldera in the Mariana Volcanic Arc. Environ Microbiol 8, 37-49 (2006).

15. Nakagawa, S. et al. Distribution, phylogenetic diversity and physiological characteristics of epsilon-Proteobacteria in a deep-sea hydrothermal field. Environ. Microbiol 7, 1619-1632 (2005).

16. Takai, K., Komatsu, T. Inagari, F. \& Horikoshi, K. Distribution of Archaea in a black smoker chimney structure. Appl. Environ. Microbiol 67, 3618-3629 (2001).

17. Moussard, H. et al. Thermophilic lifestyle for an uncultured archaeon from hydrothermal vents: evidence from environmental genomics. Appl. Environ. Microbiol 72, 2268-2271 (2006). 
18. Ishibashi, J., et al. Expedition reveals changes in Lau Basin hydrothermal system. Eos, Trans. Am. Geophys. Union 87, 13-17 (2006).

19. Inagaki, F. et al. Biogeographical distribution and diversity of microbes in methane hydrate-bearing deep marine sediments on the Pacific Ocean Margin. Proc. Natl. Acad. Sci U S A. 103, 2815-2820 (2006).

20. Segerer, A., Langworthy, T. A. \& Stetter, K. O. Thermoplasma acidophilum and Thermoplasma volcanium sp. nov. from solfatara fields. Syst. Appl. Microbiol 10, 161$171(1988)$.

21. Langmuir, C. H., et al. Hydrothermal prospecting and petrological sampling in the Lau Basin: Background data for the integrated study site. Eos Trans. American Geophysical Union, 85, B13A-0189 (2004).

22. Macalady, J. L. et al. Membrane monolayers in Ferroplasma spp.: a key to survival in acid. Extremophiles 8, 411-419 (2004).

23. Schleper, C. et al. Picrophilus gen. nov., fam. nov.: a novel aerobic, heterotrophic,thermoacidophilic genus and family comprising Archaea capable of growth around pH 0. J. Bacteriol 177, 7050-7059 (1995).

24. Beveridge, T. J. Structures of Gram-negative cell walls and their derived membrane vesicles. J. Bacteriol 7, 253-260. (1999).

25. Sleytr, U. B. \& Beveridge, T. J. Bacterial S-layers. Trends Microbiol. 7, 253 260 (1999).

26. Ludwig, W., et al. ARB: a software environment for sequence data. Nucleic Acids Res. 32, 1363-1371 (2004).

27. Olsen, G., Matsuda H., Hagstrom R. \& Overbeek R. FastDNAmL: a tool for construction of phylogenetic trees of DNA sequences using maximum likelihood. Computer Appl. Biosci 10, 41-48 (1994). 
28. Hopmans, E. C., et al. Analysis of intact tetraether lipids in archaeal cell material and sediments by high performance liquid chromatography/atmospheric pressure chemical ionization mass spectrometry. Rap. Comm. Mass. Spectrom 14, 585$589(2000)$.

29 Segerer, A., Langworthy, T. A. \& Stetter, K. O. Thermoplasma acidophilum and Thermoplasma volcanium sp. nov. from solfatara fields. Syst. Appl. Microbiol 10, 161171 (1988).

30 Schleper, C. et al. Picrophilus gen. nov., fam. nov.: a novel aerobic, heterotrophic, thermoacidophilic genus and family comprising Archaea capable of growth around pH 0. J. Bacteriol 177, 7050-7059 (1995).

Supplementary Information is linked to the online version of the paper at www.nature.com/nature.

Acknowledgements We thank the crew of the $R / V$ Melville, $R / V$ Atlantis and the $D S R O V$ Jason II and $D S V$ Alvin teams for their assistance. This work is funded by grants from the US National Science Foundation (NSF, A.L.R., M.K.T, K.L.V.D.), a PSU Faculty Enhancement Award (A.L. R.), the Natural Science and Engineering Research Council of Canada (NSERC), and the US-Department of Energy (T.J.B.) and US-National Research Program, Water Resources Division, USGS and NASA Exobiology (MAV). We thank Dianne Moyles and Bob Harris for their technical help with TEM; Paul Craddock for XRD; Marianne Baas and Ellen Hopmans for analytical assistance with the lipid analyses, Isabelle Cozzarelli, Michael Doughten and Jeanne Jaeschke (USGS) for the organic acid analysis; Galen Sincerny, Andrew O’Neill and Debra Decker for their assistance; and Isabel Ferrera for sharing QPCR results. Jean Euzeby and Mike Bartlett are acknowledged for assistance with naming the new archaeon.

Author Contributions A. L. R. and Y. L. isolated and characterized the acidophile; A. B. B. did all molecular phylogenetic and environmental DNA analyses. M. A. V. and J. T. K. did the qPCR analysis, 
T. T. B. did the ultrastructure analysis and interpretation, and S. S. performed membrane lipid analysis. M. K. T. provided XRD data and geochemical interpretation. K. L. V. D. provided samples, data on the sample locations and geochemical context. All authors discussed the results and commented on the manuscript.

Author Information Reprints and permissions information is available at npg.nature.com/reprintsandpermissions. The new sequences described in this manuscript have been deposited in GenBank accession numbers DQ451875 (T469) and DQ451876 (T449). The authors declare that they have no competing financial interests. Correspondence and requests for materials should be addressed to A. L. R. (reysenbacha@pdx.edu). 
Figure 1. Phylogenetic relationships between 16S rRNA sequences from strain T469 and representatives of the DHVE2 and Euryarchaeota. The tree was inferred using maximum-likelihood analysis. The scale bar represents the number of 0.1 substitutions per nucleotide position. The numbers at the branch nodes are bootstrap values ( $>70 \%)$ based on 100 bootstrap resamplings.

Figure 2. Electron photomicrographs of T469. a. A negatively stained electron micrograph image showing the S-layer and the initiation of vesicle formation. b. Negatively stained electron micrograph image showing the flagellum. c. Detail of the flagellum with thicker sheath area on right. d. Multiple vesicles with the thick S-layer. e. A thin section of a cell showing the bending of the S-layer. Scale bar is $200 \mathrm{~nm}$. 
Table 1. Percent abundance of DHVE2 as compared to total Archaea at sites along two ridge systems, the East Pacific Rise (EPR, 9 90.3' N, $104^{\circ} 17.5^{\prime} \mathrm{W}$ to $9^{\circ} 33.5 \mathrm{~N}, 104^{\circ} 14.9^{\prime} \mathrm{W}$ ) and the Eastern Lau Spreading Center (ESLC, $2^{\circ} 3.2^{\prime} \mathrm{S} 176^{\circ} 8^{\prime} \mathrm{W}$ to $22^{\circ} 10.8^{\prime} \mathrm{S}, 176^{\circ} 36.1^{\prime} \mathrm{W}$ ).

\begin{tabular}{|c|c|c|c|}
\hline Site & $\begin{array}{l}\text { DHVE/Archaea } \\
\text { (\% Range) }\end{array}$ & $\begin{array}{l}\text { DHVE/Archaea } \\
\text { (\% Average) }\end{array}$ & $\begin{array}{l}\text { DHVE/Archaea } \\
\text { (\% Median) }\end{array}$ \\
\hline $\begin{array}{l}\text { Kilo Mauna } \\
(n=3)^{*}\end{array}$ & $0.08-6.21$ & 2.16 & 0.2 \\
\hline $\begin{array}{l}\text { Tow Cam } \\
(n=5)^{*}\end{array}$ & $0.5-14.8$ & 4.35 & 2.11 \\
\hline $\begin{array}{l}A B E \\
(n=3)^{*}\end{array}$ & $0.5-5.3$ & 3.19 & 3.78 \\
\hline $\begin{array}{l}\text { Tui Malila } \\
(n=8)^{*}\end{array}$ & $0.1-13.2$ & 3.96 & 2.87 \\
\hline $\begin{array}{l}\text { Mariner } \\
(n=6)^{*}\end{array}$ & $0.01-5.0$ & 1.28 & 0.26 \\
\hline $\begin{array}{l}\text { ESLC Total } \\
(n=25)^{\star}\end{array}$ & $0.01-15$ & 2.98 & 1.20 \\
\hline $\begin{array}{l}\text { EPR } \\
(n=4)^{*}\end{array}$ & $0.75-10$ & 3.28 & 1.37 \\
\hline
\end{tabular}

*number of samples analysed. qPCR of each sample was run in duplicate. 
Table 2. Summary of phenotypic characteristics of the T469 and its closest thermophilic relatives.

\begin{tabular}{|c|c|c|c|}
\hline & T469 & $\begin{array}{l}\text { Thermoplasma } \\
\text { spp }^{29}\end{array}$ & Picrophilus spp ${ }^{30}$ \\
\hline Morphology & Pleiomorphic cocci & Pleiomorphic cocci & Pleiomorphic cocci \\
\hline Flagella & + & - & - \\
\hline S-layer present & + & - & + \\
\hline Metabolism* & O & $\mathrm{O}, \mathrm{M}$ & $\mathrm{O}$ \\
\hline Electron donor & $\begin{array}{l}\text { Yeast extract, casein, } \\
\text { trypticase peptone }\end{array}$ & $\begin{array}{l}\text { Yeast extract, meat } \\
\text { extract, some } \\
\text { sugars }\end{array}$ & Yeast extract, tryptone \\
\hline Electron acceptor & $\mathrm{Fe}^{3+}, \mathrm{S}^{\circ}$ & $\begin{array}{l}\text { Complex organic } \\
\text { carbon, } \mathrm{S}^{\circ}\end{array}$ & $\begin{array}{l}\text { Complex organic } \\
\text { carbon, } \mathrm{O}_{2}\end{array}$ \\
\hline Aerobic growth & - & + & + \\
\hline Anaerobic growth & + & + & - \\
\hline Marine/terrestrial & marine & $\begin{array}{l}\text { marine and } \\
\text { terrestrial }\end{array}$ & terrestrial \\
\hline $\begin{array}{l}\text { Temperature range } \\
{ }^{\circ} \mathrm{C} \text { (opt) }\end{array}$ & $55-75(70)$ & $33-67(60)$ & $47-65(60)$ \\
\hline pH range (opt) & $3.3-5.8(4.5)$ & $0.5-4(2)$ & $0-3.5(0.7)$ \\
\hline
\end{tabular}

O chemoorganotroph (heterotroph), M chemomixotroph 


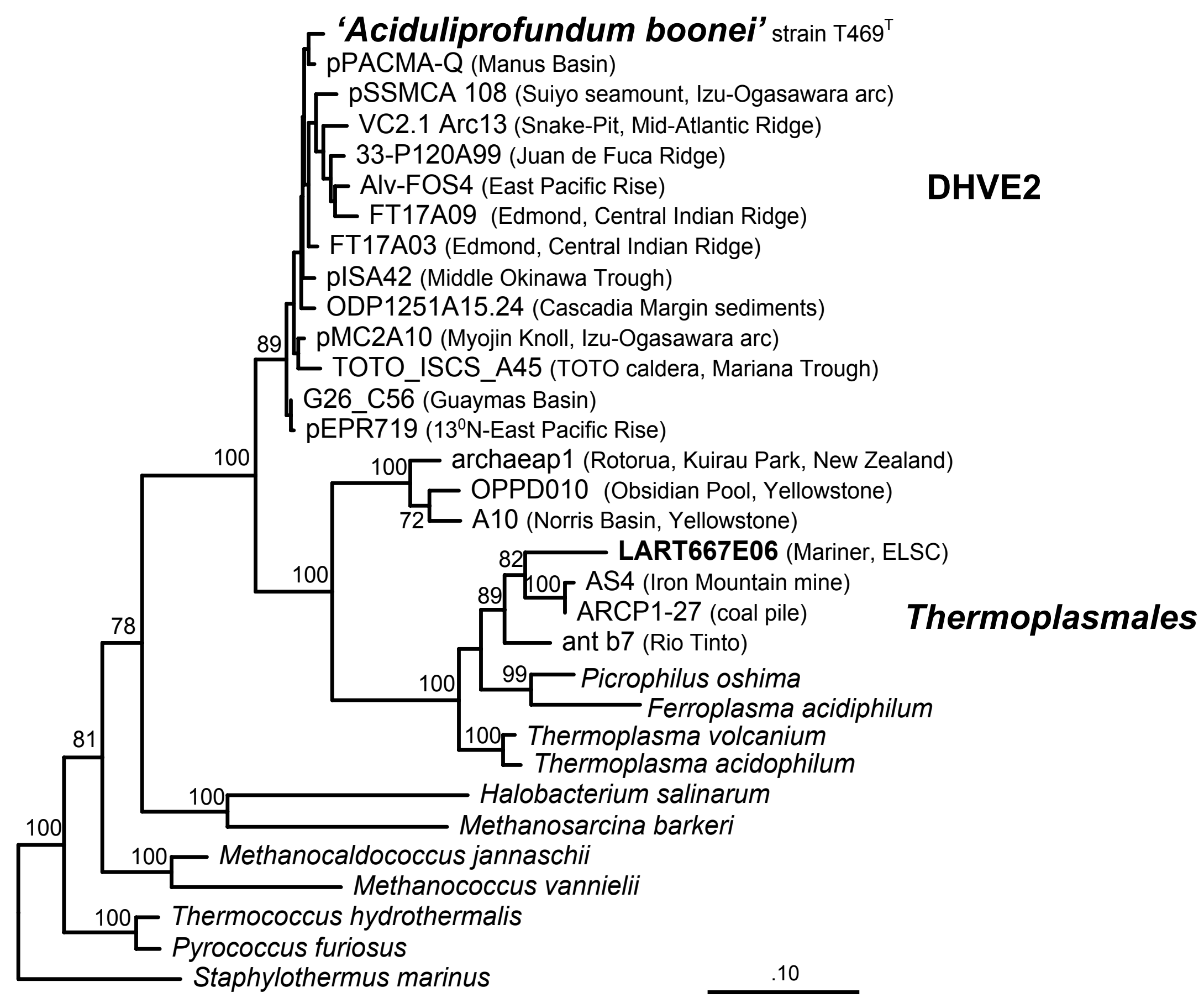




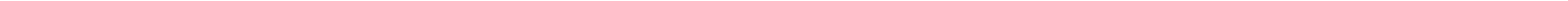




\section{Supplementary Methods}

\section{Culturing media and conditions.}

Culturing medium. Anaerobic marine media contained $300 \mathrm{ml}$ of anaerobic MH buffer $(87.75 \mathrm{~g}$ $\left.1^{-1} \mathrm{NaCl}, 5.0 \mathrm{~g} \mathrm{l}^{-1} \mathrm{MgCl}_{2} .6 \mathrm{H}_{2} \mathrm{O}, 1.5 \mathrm{~g} \mathrm{l}^{-1} \mathrm{KCl}_{2}, 6.0 \mathrm{~g} \mathrm{l}^{-1} \mathrm{NaOH}\right),\left(\mathrm{NH}_{4}\right)_{2} \mathrm{SO}_{4}\left(1.3 \mathrm{gl}^{-1}\right), \mathrm{KH}_{2} \mathrm{PO}_{4}$ $\left(0.28 \mathrm{~g} \mathrm{l}^{-1}\right), \mathrm{MgSO}_{4} \cdot 7 \mathrm{H}_{2} \mathrm{O}\left(0.25 \mathrm{~g}^{-1}\right), \mathrm{CaCl}_{2} .2 \mathrm{H}_{2} \mathrm{O}\left(0.07 \mathrm{~g}^{-1}\right), \mathrm{FeCl}_{3} .6 \mathrm{H} 2 \mathrm{O}\left(4 \mathrm{mg} \mathrm{l}^{-1}\right)$, $\mathrm{MnCl}_{2} .4 \mathrm{H}_{2} \mathrm{O}(0.36 \mathrm{mg}), \mathrm{Na}_{2} \mathrm{~B}_{4} \mathrm{O}_{7} .10 \mathrm{H}_{2} \mathrm{O}\left(4.5 \mathrm{mg} \mathrm{l}^{-1}\right), \mathrm{ZnSO}_{4} .7 \mathrm{H}_{2} \mathrm{O}\left(0.22 \mathrm{mg} \mathrm{l}^{-1}\right)$, $\mathrm{CuCl}_{2} .2 \mathrm{H}_{2} \mathrm{O}\left(0.05 \mathrm{mg} \mathrm{l}^{-1}\right), \mathrm{Na}_{2} \mathrm{MoO}_{4} \cdot 2 \mathrm{H}_{2} \mathrm{O}\left(0.03 \mathrm{mg} \mathrm{l}^{-1}\right), \mathrm{VOSO}_{4} \cdot 2 \mathrm{H}_{2} \mathrm{O}(0.03 \mathrm{mg}), \mathrm{CoSO}_{4}(0.01$ $\left.\mathrm{mg}^{-1}\right)$, trisodium citrate $\left(2.94 \mathrm{~g}^{-1}\right)$, trypticase peptone $\left(1.0 \mathrm{~g}^{-1}\right)$, yeast extract $\left(1.0 \mathrm{~g}^{-1}\right)$, resazurin $(1.0 \mathrm{mg}), \mathrm{Na}_{2} \mathrm{~S}_{2} 9 \mathrm{H}_{2} \mathrm{O}\left(0.50 \mathrm{~g} \mathrm{l}^{-1}\right)$, sulphur $\left(10.0 \mathrm{~g} \mathrm{l}^{-1}\right)$. The $\mathrm{pH}$ was adjusted to 4.5 with $\mathrm{H}_{2} \mathrm{SO}_{4}$, and media was dispensed anaerobically under an atmosphere of $\mathrm{N}_{2}: \mathrm{CO}_{2}(80: 20, \mathrm{v} / \mathrm{v}$, $100 \mathrm{kPa})$.

Carbon sources. The following carbon sources were tested in media $\left(\mathrm{pH} 4.5,70^{\circ} \mathrm{C}\right)$ containing vitamins or $0.01 \%$ yeast extract : arabinose $(0.2 \%)$, acrylate $(20 \mathrm{mM})$, acetate $(20 \mathrm{mM})$, butyrate $(20 \mathrm{mM})$, benzoate $(20 \mathrm{mM}), 1$-butanol $(20 \mathrm{mM})$, 2-butanol $(20 \mathrm{mM})$, cellobiose $(20 \mathrm{mM})$, caproate $(20 \mathrm{mM})$, casein $(0.2 \%)$, casimino acids $(0.2 \%)$, crotonate $(20 \mathrm{mM})$, ethanol $(20 \mathrm{mM})$, formate $(40 \mathrm{mM})$, fumarate $(20 \mathrm{mM})$, fructose $(0.2 \%)$, formamide $(20 \mathrm{mM})$, galactose $(0.2 \%)$, gelatin $(0.2 \%)$, glucose $(0.2 \%)$, lactate $(20 \mathrm{mM})$, maltose $(0.2 \%)$, mannose $(0.2 \%)$, malate $(20$ $\mathrm{mM})$, methanol $(20 \mathrm{mM})$, propionate $(20 \mathrm{mM})$, starch $(0.2 \%)$, sucrose $(0.2 \%)$, trypticase $(0.2 \%)$, trimethyamine $(20 \mathrm{mM})$, valerate $(20 \mathrm{mM})$, yeast extract $(0.2 \%)$, xylose $(0.2 \%)$. Growth only occurred in media containing casein, trypticase peptone or yeast extract. Acetate and formate were detected as products after growth on these complex organics.

Electron acceptors. In the absence of sulphur, growth did not occur in the presence of cysteine $(\mathrm{O} .05 \%, \mathrm{w} / \mathrm{v})$, thiosulphate $(0.1 \%, \mathrm{w} / \mathrm{v})$ or nitrate $(0.5 \% \mathrm{w} / \mathrm{v})$. Poor growth was detected in media containing polysulphides. However growth did occur in the presence if ferric citrate $(15 \mathrm{mM})$, and was converted to ferrous iron (Ferrozine assay). In this case, the reducing agent, CoM (mercaptoethanesulfonic acid, $0.05 \%$, w/v) was used instead of sulphide. Sulphide was measured according to Cline, $1969^{1}$.

Oxygen sensitivity. Oxygen sensitivity was tested in unreduced anaerobic medium with 1 to $20 \%$ oxygen added. Growth occurred in the unreduced anaerobic medium, but not in the medium with added oxygen. 


\section{DNA Extraction and 16S rRNA sequence analysis.}

Genomic DNA was isolated from sulphide samples using the UltraClean Soil DNA Isolation Kit (MoBio) and from cultures using the Dneasy Tissue Kit (Qiagen). 16S rRNA genes were amplified by PCR using the archaeal-specific 21F and 'universal' 1492R primers for culture identification and 21F and 'universal' 1391R for clone library construction. Products were cloned using the TOPO TA cloning Kit (Invitrogen) for environmental clone libraries. For pure cultures, the PCR products were purified using the UltraClean PCR Clean-up Kit (MoBio) and sequenced directly using the BigDye Terminator v3.1 Cycle Sequencing Kit and a 3100 Genetic Analyzer (Applied Biosystems). Sequences were manually aligned based on secondary structure constraints in the ARB software package ${ }^{2}$. Phylogenetic relationships were determined using evolutionary distance and maximum likelihood analysis. Alternative methods such as maximumparsimony produced phylogenetic trees with similar topologies.

\section{Detection of DHVE2 from environmental samples by DGGE and QPCR}

QPCR. PCR was performed according to manufacturers' instructions using the Quantitect SYBR green PCR kit (Qiagen, Inc, Valencia, CA) and $0.8 \mu \mathrm{M}$ final primer concentration. A plasmid containing 16S rRNA gene insert from DHVE2 strain T469 was used as quantification standard for DHVE2 and total archaeal qPCR. 16S rRNA primers used were a newly designed primer DHVE2-1038f (5'-CGACYTTGCCCGAATAAGAGCC-3') and DHVE2-1159r (5'GGTCTCCCCAGTGTGCTCTGCC-3') $)^{3}$ for the DHVE amplifications and $\operatorname{arc} 915 f\left(5^{\prime}\right.$ AGGAATTGGCGGGGGAGCAC-3') and arc1059r (GCCATGCACCWCCTCT-3') ${ }^{4}$ for total Archaea. PCR cycling conditions for DHVE2 qPCR was 1 cycle at $15 \mathrm{~min} 95^{\circ} \mathrm{C}$ denature/polymerase activation followed by 40 cycles at $95^{\circ} \mathrm{C}$ for $30 \mathrm{sec}, 62^{\circ} \mathrm{C}$ for $30 \mathrm{sec}, 72^{\circ} \mathrm{C}$ for $30 \mathrm{sec}, 84^{\circ} \mathrm{C}$ for $7 \mathrm{sec}$ followed by a fluorescence measurement after each cycle. Conditions were the same for total Archaea except that the annealing temperature was $60^{\circ} \mathrm{C}$ and 35 cycles were performed.

Cell number calculation from qPCR. PCR conditions and primer concentrations for DHVE2 and total archaeal qPCR were optimized for specificity by using non target template (from cultures, e.g. Persephonella, Methanocaldococcus) obtained from similar environmental samples. High amplification efficiency $(>97 \%)$ was maintained with optimized specificity. Cell numbers were calculated assuming archaeal 16S rRNA gene copy number of $1.5 /$ cell (http://rrndb.cme.msu.edu/rrndb/servlet/controller), calculated as cell number/ $\mu \mathrm{L}$ DNA extracted. 
The detection limits for the DHVE2 and total archaeal specific qPCR reactions were 1 cell and 5 cells, respectively.

PCR for denaturing gradient gel electrophoresis (DGGE). PCR conditions were as follows: a $50 \mu 1$ reaction contained 1-5 $\mu 1$ DNA, $5 \mu 1$ of 10X Promega PCR buffer B, $2 \mathrm{mM} \mathrm{MgCl}_{2}, 10$ pmol dNTPs, 20 pmol of each primer (archaeal-specific-344F-GC: 5'CGCCCGCCGCGCCCCGCGCCCGTCCCGCCGCCCCCGCCACGGGGCGCAGCAGGCGC GA -3' and DHVE-specific-601R: 5' -AGCRCCRGGATTTACCCAG-3'), and 1 U of Taq DNA Polymerase (Promega). Thermal cycling conditions were: 2 min at $94^{\circ} \mathrm{C}$, followed by 35 to 40 cycles of $20 \mathrm{sec}$ at $94^{\circ} \mathrm{C}, 20 \mathrm{sec}$ at $50^{\circ} \mathrm{C}$, and $45 \mathrm{sec}$ at $72^{\circ} \mathrm{C}$ and a final $10 \mathrm{~min}$ at $72^{\circ} \mathrm{C}$.

Denaturing gradient gel electrophoresis (DGGE). Samples were analyzed by Denaturing Gradient Gel Electrophoresis (DGGE) of DHVE-specific 16S rRNA genes to visualize changes in the community. Amplified products were sorted on a denaturing gradient $(30 \%$ to $70 \%$ urea/formamide, $100 \%$ denaturant $=40 \%(\mathrm{vol} / \mathrm{vol})$ formamide and $7 \mathrm{M}$ urea $)$ acrylamide $(6 \%)$ gel for 4 hours at $200 \mathrm{~V}$ and $60^{\circ} \mathrm{C}$ in $1 \mathrm{X}$ TAE buffer $(0.04 \mathrm{M}$ Tris base, $0.02 \mathrm{M}$ acetate, and 1.0 mM EDTA). Gels were stained for $30 \mathrm{~min}$ in SYBRGreen $(1: 20,000)$ and destained in $1 \mathrm{X}$ TAE for 10 min. DNA from the individual bands was reamplified from the gel and sequenced. Individual bands of DNA were probed with a sterile pipette tip and placed in $30 \mu 1$ filter sterilized $10 \mathrm{mM}$ Tris $(\mathrm{pH} 8)$ for 5 min. The Tris-DNA mixture $(6 \mu 1)$ was used as template for PCR as described above using the primers 361FN : 5'-ACGGGGCGCAGCAGGCGCGA-3'and DHVE$601 \mathrm{R}$.

Sequencing of select DGGE bands. PCR products were purified with the UltraClean PCR Clean-up Kit (Mo Bio Laboratories) and sequenced on an ABI 3100 DNA sequencer using the BigDye terminator cycle sequencing kit (Applied Biosystems). Sequences were assembled and edited using Lasergene and compared to Genbank using BLAST.

\section{Membrane lipid analysis}

Membrane lipids were extracted by refluxing cell material with $1 \mathrm{~N} \mathrm{KOH}$ in methanol and partitioning with a water/dichloromethane mixture. The crude lipid extract was fractionated over an alumina oxide column using a 1:1 dichloromethane/methanol mixture as eluent to obtain the polar fraction. This fraction was taken up in a 99:1 hexane:isopropanol mixture, filtered using a $0.4 \mu \mathrm{m}$ pore size Teflon filter. 


\section{Organic acid analysis.}

Organics acids (formate, acetate, proprionate) were measured by ion chromatography on a Dionex ED50 Electrochemical Detector.

\section{Mineral characterization by XRD.}

The mineral composition of the outer 1 to $2 \mathrm{~mm}$ of two samples containing DHVE2 from ESLC and one from the Central Indian Ridge (CIR, Edmond vent Field) was identified by X-ray diffraction.

\section{Transmission electron microscopy.}

For negative stains both growing and glutaraldehyde-fixed cells were used. In both instances, a grid was floated on a cell suspension, washed with deionized water and treated with $0.1 \%$ peptone as a wetting agent before staining with either $2 \%$ uranyl acetate or $2 \%$ ammonium molybdate. For thin sections, cells were fixed with $2 \%$ glutaraldehyde followed by $2 \%$ osmium tetroxide, enrobed in Noble agar, 'en bloc' stained with $2 \%$ uranyl acetate, dehydrated through an ethanol series to LR White embedding resin. After curing the blocks were sectioned and the sections stained with uranyl acetate and lead citrate ${ }^{5}$. 
Supplementary Table 1. Published reports of the presence of DHVE2 in archaeal clone

libraries.

\begin{tabular}{|c|c|c|c|c|c|c|c|}
\hline Location & Lat/long & Sample & $\begin{array}{l}\text { \% clone } \\
\text { library }\end{array}$ & Example clone & $\begin{array}{l}\text { Genbank } \\
\text { Accession } \\
\#\end{array}$ & Sample type & Ref \\
\hline $\begin{array}{l}\text { Axial Volcano (Juan de } \\
\text { Fuca Ridge), North } \\
\text { Pacific Ocean }\end{array}$ & $\begin{array}{l}46^{\circ} \mathrm{N} \\
130^{\circ} \mathrm{W}\end{array}$ & 33-PA99 & 6.7 & 33-P127A99 & AF355837 & $\begin{array}{l}\text { hydrothermal } \\
\text { fluids }\end{array}$ & 6 \\
\hline $\begin{array}{l}\text { Axial Volcano (Juan de } \\
\text { Fuca Ridge), North } \\
\text { Pacific Ocean }\end{array}$ & $\begin{array}{l}46^{\circ} \mathrm{N} \\
130^{\circ} \mathrm{W}\end{array}$ & 33-PA98 & 6.1 & 33-P23A98 & AF355840 & $\begin{array}{l}\text { hydrothermal } \\
\text { fluids }\end{array}$ & 6 \\
\hline $\begin{array}{l}\text { Guaymas Basin (Sea of } \\
\text { Cortez), Pacific Ocean }\end{array}$ & $\begin{array}{l}27^{\circ} \mathrm{N} \\
110^{\circ} \mathrm{W}\end{array}$ & G26 & 4.9 & G26_C73 & AF356637 & $\begin{array}{l}\text { hydrothermal } \\
\text { chimney }\end{array}$ & 7 \\
\hline East Pacific Rise $9^{\circ} \mathrm{N}$ & $\begin{array}{l}9^{\circ} 50^{\prime} \mathrm{N} \\
104^{\circ} 18^{\prime} \mathrm{N}\end{array}$ & $\mathrm{CH}$ & 1.5 & clone $\mathrm{CH} 8 \_7 \mathrm{a}$ & AY672495 & $\begin{array}{l}\text { hydrothermal } \\
\text { chimney }\end{array}$ & 8 \\
\hline $\begin{array}{l}\text { East Pacific Rise } 13^{\circ} \mathrm{N}, \\
\text { Pacific Ocean }\end{array}$ & $\begin{array}{l}12^{\circ} 48^{\prime} \mathrm{N} \\
104^{\circ} \mathrm{W}\end{array}$ & pEPR & ND* & pEPR122 & AF526963 & $\begin{array}{l}\text { hydrothermal } \\
\text { sample }\end{array}$ & 3,9 \\
\hline $\begin{array}{l}\text { Myojin Knoll (Izu- } \\
\text { Ogasawara Arc), North } \\
\text { western Pacific Ocean }\end{array}$ & $\begin{array}{l}32^{\circ} 06^{\prime} \mathrm{N} \\
139^{\circ} 52^{\prime} \mathrm{E}\end{array}$ & pMC2 & 33.0 & pMC2A24 & AB019736 & $\begin{array}{l}\text { hydrothermal } \\
\text { chimney }\end{array}$ & 10 \\
\hline $\begin{array}{l}\text { Myojin Knoll (Izu- } \\
\text { Ogasawara Arc), North } \\
\text { western Pacific Ocean }\end{array}$ & $\begin{array}{l}28^{\circ} 34^{\prime} \mathrm{N} \\
140^{\circ} 38^{\prime} \mathrm{E}\end{array}$ & pSSMCA & 4.8 & pSSMCA108 & AB019740 & $\begin{array}{l}\text { hydrothermal } \\
\text { chimney }\end{array}$ & 10 \\
\hline $\begin{array}{l}\text { Iheya Basin (Middle } \\
\text { Okinawa Trough), } \\
\text { Northwestern Pacific } \\
\text { Ocean }\end{array}$ & $\begin{array}{l}27^{\circ} 32^{\prime} . \mathrm{N} \\
126^{\circ} 58^{\prime} \mathrm{E}\end{array}$ & pISA & 29.8 & pISA12 & AB019741 & $\begin{array}{l}\text { hydrothermal } \\
\text { sediments }\end{array}$ & 10 \\
\hline $\begin{array}{l}\text { Pacmanus (Manus } \\
\text { Basin), Western Pacific } \\
\text { Ocean }\end{array}$ & $\begin{array}{l}03^{\circ} 43^{\prime} \mathrm{S} \\
151^{\circ} 40^{\prime} \mathrm{E}\end{array}$ & pPACMA & $6.8-22.9$ & pPACMA-M & AB052983 & $\begin{array}{l}\text { hydrothermal } \\
\text { chimney }\end{array}$ & 11 \\
\hline $\begin{array}{l}\text { Snake Pit (Mid-Atlantic } \\
\text { Ridge), Atlantic Ocean }\end{array}$ & $\begin{array}{l}23^{\circ} 22^{\prime} \mathrm{N} \\
44^{\circ} 57^{\prime} \mathrm{W}\end{array}$ & $\mathrm{VC} 2.1$ & 4.0 & VC2.1 Arc6 & AF068817 & $\begin{array}{l}\text { hydrothermal } \\
\text { sample }\end{array}$ & 12 \\
\hline $\begin{array}{l}\text { Edmond Vent Field } \\
\text { (Central Indian Ridge), } \\
\text { Indian Ocean }\end{array}$ & $\begin{array}{l}23^{\circ} \mathrm{S} \\
69^{\circ} \mathrm{E}\end{array}$ & FT17A & 93.0 & FT17A03 & AY251064 & $\begin{array}{l}\text { hydrothermal } \\
\text { chimney }\end{array}$ & 13 \\
\hline $\begin{array}{l}\text { TOTO caldera (Mariana } \\
\text { Volcanic Arc), Western } \\
\text { Pacific Ocean }\end{array}$ & $\begin{array}{l}12^{\circ} 42^{\prime} \mathrm{N} \\
143^{\circ} 32^{\prime} \mathrm{E}\end{array}$ & TOTO & 35.7 & TOTO-A6-12 & AB167486 & $\begin{array}{l}\text { hydrothermal } \\
\text { chimney }\end{array}$ & 14 \\
\hline $\begin{array}{l}\text { Cascadia Margin-eastern } \\
\text { Pacific-Deep Marine } \\
\text { Sediments, Eastern } \\
\text { Pacific Ocean }\end{array}$ & $\begin{array}{l}44^{\circ} 34^{\prime} \mathrm{N}, \\
125^{\circ} 04^{\prime} \\
\mathrm{W}\end{array}$ & 1251 & ND* & $\begin{array}{l}\text { ODP1251A15.2 } \\
4\end{array}$ & AB177273 & $\begin{array}{l}\text { Deep marine } \\
\text { sediments } \\
(123-304 \\
\text { mbsf })\end{array}$ & 15 \\
\hline
\end{tabular}

* not determined 
Supplementary Table 2. Sites on the EPR and ELSC where DHVE2 16S rRNA gene sequences were detected using primers specific for DHVE2 and by sequencing bands from DGGE gels (e.g, Supplementary Fig. 1). Thirty-six of sixty- three samples collected on three separate cruises that were tested using PCR and DGGE were positive for DHVE2.

\begin{tabular}{|c|c|c|}
\hline $\begin{array}{l}\text { Sample Type (\# of different samples } \\
\text { containing DHVE2/total samples tested)* }\end{array}$ & Site & Lat/Long \\
\hline \multicolumn{3}{|l|}{ East Pacific Rise (EPR) $^{16}$} \\
\hline Outer $3 \mathrm{~mm}$ soft sulfides $(1 / 1)$ & SW vent area & $21^{\circ} 50 \mathrm{~N}, 109^{\circ} 07^{\prime} \mathrm{W}$ \\
\hline Outer $1-3 \mathrm{~mm}$ edges $(1 / 1)$ & Lvent & $\begin{array}{l}9^{\circ} 46.3 \mathrm{~N}, \\
104^{\circ} 16.7^{\prime} \mathrm{W}\end{array}$ \\
\hline Outer1-3mm crust $(1 / 1)$ & E vent & $\begin{array}{l}9^{\circ} 33.5 \mathrm{~N} \\
104^{\circ} 14.9^{\prime} \mathrm{W}\end{array}$ \\
\hline Outer $1 \mathrm{~mm}$ crust of turret (1/1) & Robin's Roost & $\begin{array}{l}9^{\circ} 50 \mathrm{~N}, \\
104^{\circ} 17.5^{\prime} \mathrm{W}\end{array}$ \\
\hline $\begin{array}{l}\text { Multiple samples, iron oxides, outer } \sim 2 \mathrm{~mm} \\
(3 / 3)\end{array}$ & F vent & $\begin{array}{l}9^{\circ} 16.18^{\prime} \mathrm{N} \\
104^{\circ} 13.1^{\prime} \mathrm{W}\end{array}$ \\
\hline Outer $1-3 \mathrm{~mm}$ crust $(1 / 2)$ & P vent & $\begin{array}{l}9^{\circ} 50.3^{\prime} \mathrm{N} \\
104^{\circ} 17.5^{\prime} \mathrm{W}\end{array}$ \\
\hline Outer $\sim 2 \mathrm{~mm}$ crust $(1 / 3)$ & Marker 22 & $\begin{array}{l}9^{\circ} 50.3^{\prime} \mathrm{N} \\
104^{\circ} 17.5^{\prime} \mathrm{W}\end{array}$ \\
\hline Outer $\sim 2 \mathrm{~mm}$ crust $(1 / 2)$ & C vent & $\begin{array}{l}9^{\circ} 38.9^{\prime} \mathrm{N} \\
104^{\circ} 15.5^{\prime} \mathrm{W}\end{array}$ \\
\hline $\begin{array}{l}\text { Outer }(\sim 2 \mathrm{~mm}) \text { and middle sections }(\sim 1 \mathrm{~cm}) \text { of } \\
\text { chimney }(3 / 5)\end{array}$ & Bio9 & $\begin{array}{l}9^{\circ} 50.3^{\prime} \mathrm{N} \\
104^{\circ} 17.5^{\prime} \mathrm{W}\end{array}$ \\
\hline $\begin{array}{l}\text { Outer iron oxide and sulfur crust } 1-2 \mathrm{~mm} \\
(1 / 2)\end{array}$ & Ty & $\begin{array}{l}9^{\circ} 50.3^{\prime} \mathrm{N} \\
104^{\circ} 17.5^{\prime} \mathrm{W}\end{array}$ \\
\hline Outer $1-2 \mathrm{~mm}$ sulfur crust $(1 / 2)$ & Bio9” & $\begin{array}{l}9^{\circ} 50.3^{\prime} \mathrm{N} \\
104^{\circ} 17.5^{\prime} \mathrm{W}\end{array}$ \\
\hline Soft beehive structure $(2 / 2)$ & Alvinellid Pillar & $9^{\circ} 50 \mathrm{~N}, 104^{\circ} 17^{\prime} \mathrm{W}$ \\
\hline Outer $1-2 \mathrm{~mm}$ sulfur crust $(1 / 3)$ & Biovent & $9^{\circ} 51 \mathrm{~N}, 104^{\circ} 17^{\prime} \mathrm{W}$ \\
\hline Outer $\sim 2 \mathrm{~mm}$ black crust $(2 / 2)$ & M vent & $9^{\circ} 51 \mathrm{~N}, 104^{\circ} 18^{\prime} \mathrm{W}$ \\
\hline Outer $1-2 \mathrm{~mm}$ iron oxide crusts $(1 / 1)$ & A vent & $\begin{array}{l}9^{\circ} 46.5^{\prime} \mathrm{N} \\
104^{\circ} 17.5^{\prime} \mathrm{W}\end{array}$ \\
\hline \multicolumn{3}{|l|}{ ESLC $^{17,18}$} \\
\hline Outer $\sim 1-3 \mathrm{~mm}$ sulfur crust $(1 / 4)$ & Kilo Moana & $20^{\circ} 3.2^{\prime} \mathrm{S} 176^{\circ} 8^{\prime} \mathrm{W}$ \\
\hline Outer $\sim 1-3 \mathrm{~mm}$ sulfur crust $(4 / 4)$ & Tow Cam & $\begin{array}{l}20^{\circ} 19.1^{\prime} \mathrm{S} \\
176^{\circ} 8.2^{\prime} \mathrm{W}\end{array}$ \\
\hline Outer $\sim 1-3 \mathrm{~mm}$ sulfur crust $(2 / 2)$ & $\mathrm{ABE}$ & $\begin{array}{l}20^{\circ} 45.7 \mathrm{~S}^{\prime}, \\
176^{\circ} 34.1{ }^{\prime} \mathrm{W}\end{array}$ \\
\hline Outer $\sim 1-3 \mathrm{~mm}$ sulfur crust $(4 / 4)$ & Tui Malila & $\begin{array}{l}21^{\circ} 59.4^{\prime} \mathrm{S} \\
176^{\circ} 34.1^{\prime} \mathrm{W}\end{array}$ \\
\hline $\begin{array}{l}\text { Outer } \sim 1-3 \mathrm{~mm} \text { sulfur or iron oxide crust } \\
(4 / 7)\end{array}$ & Mariner & $\begin{array}{l}22^{\circ} 10.8^{\prime} \mathrm{S} \\
176^{\circ} 36.1^{\prime} \mathrm{W}\end{array}$ \\
\hline
\end{tabular}

* samples where no DHVE were detected in this screen are not included in this table. 
Supplementary Table 3. Mineralogical description based on XRD analysis of the $2 \mathrm{~mm}$ superficial mineral crust coating 3 selected chimney samples where the DHVE2 were detected.

\begin{tabular}{|l|l|}
\hline Sample & XRD Description \\
\hline J2-127-1-R1 (ELSC) & $\begin{array}{l}\text { Dominantly marcasite and sulphur with minor pyrite } \\
\text { and trace halite (the sulphur (white material) and } \\
\text { halite coated colloform marcasite and minor pyrite) }\end{array}$ \\
\hline J2-135-5-R1 (ELSC) & $\begin{array}{l}\text { Dominantly barite with minor to trace halite and } \\
\text { sulphur (sulphur, halite, and likely x-ray amorphous } \\
\text { Fe-oxyhydroxide (orange color) coated dendritic } \\
\text { barite) }\end{array}$ \\
\hline $\begin{array}{l}\text { J301-11 (Edmond Vent field, Central } \\
\text { Indian Ridge) }\end{array}$ & $\begin{array}{l}\text { Dominantly sulphur with minor halite, sphalerite, } \\
\text { barite and trace chalcopyrite (the sulphur (white } \\
\text { material) and halite coated underlying barite, } \\
\text { sphalerite and chalcopyrite) }\end{array}$ \\
\hline
\end{tabular}




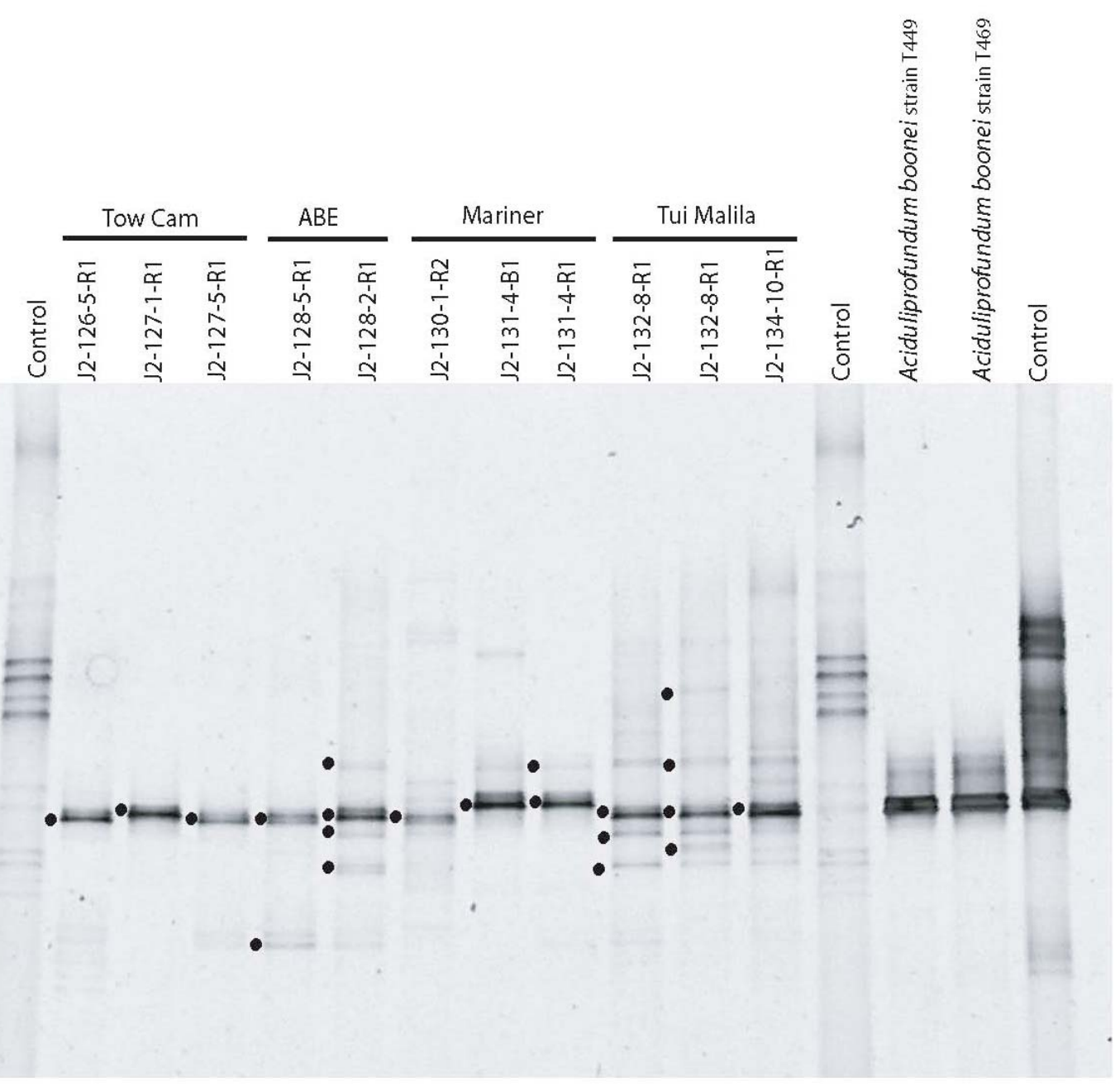

Supplementary Figure S1. Example of Denaturing Gradient Gel (DGGE) of DHVE2specific PCR products from deep sea hydrothermal vent chimneys from ELSC. Sample sites and vent field location are indicated. Also included are DHVE-specific PCR products from 2 strains of "Aciduloprofundum boonei". Dots on the gel indicate bands which have been confirmed as DHVE2 by sequencing. "Control" is a standard mixture of archaeal $16 \mathrm{~S}$ rRNA genes amplified from archaeal cultures. 


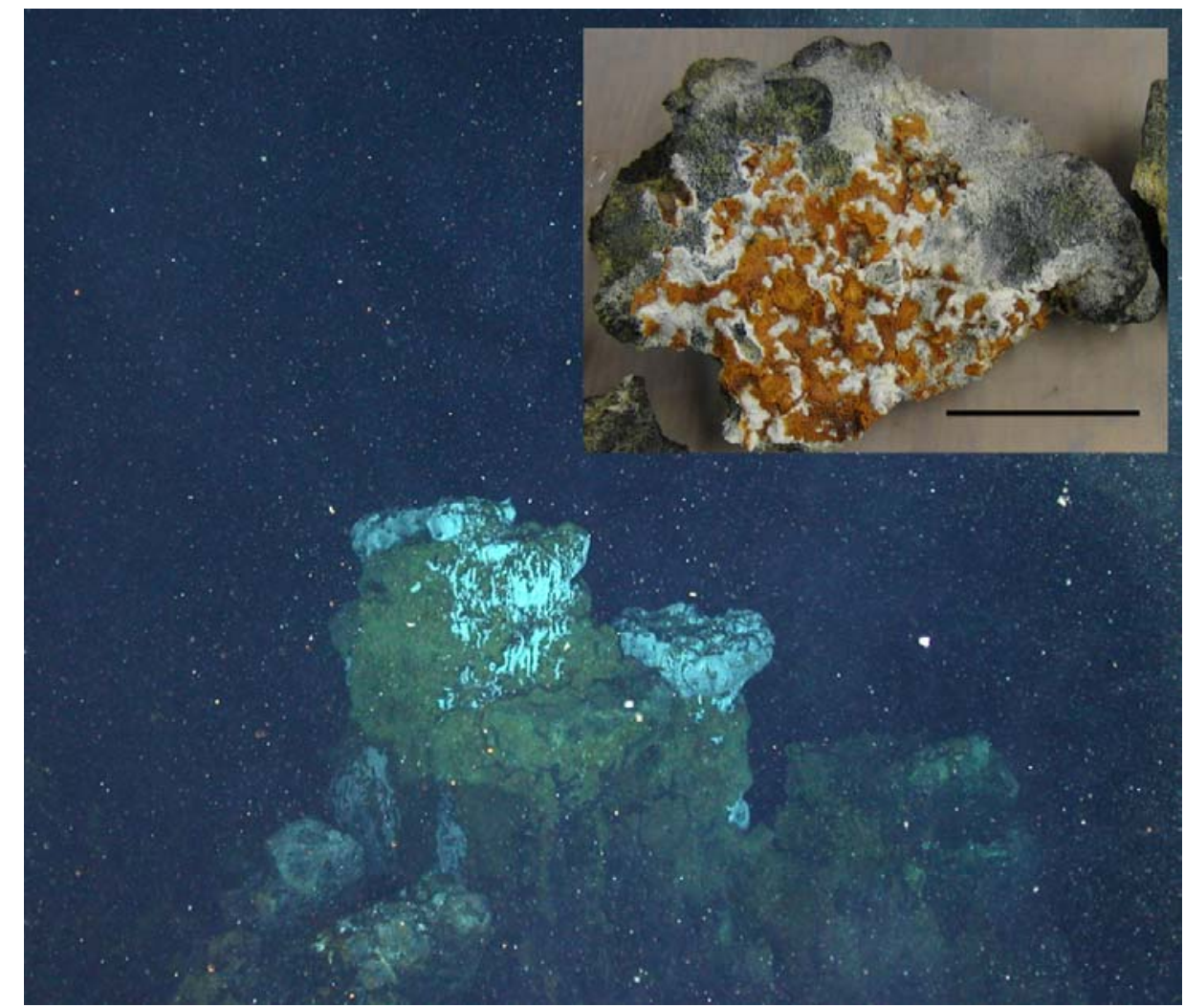

Supplementary Figure S2. Example of a vent deposit from Mariner deep-sea vents $\left(22^{\circ} 10.82^{\prime} \mathrm{S}, 176^{\circ} 36.09^{\prime} \mathrm{W}\right)$ and the outer accumulations of iron-oxide and sulphur biofilms (inset) typically where DHVE2 are detected. The temperature at the surface of this structure was about $50^{\circ} \mathrm{C}$. Strain $\mathrm{T} 469$ was obtained from a subsample of this structure. Inset scale bar is 5 $\mathrm{cm}$. 


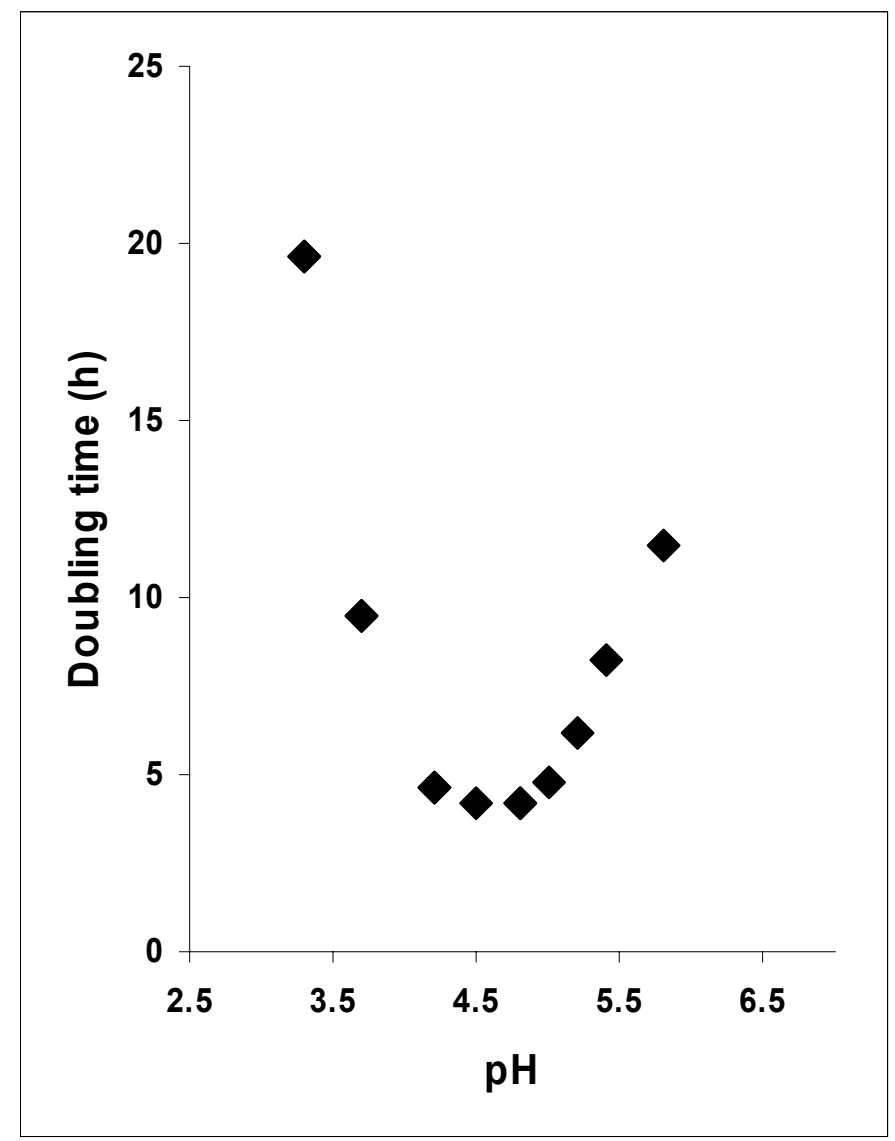

Supplementary Figure S3. Effect of pH on the growth of T469. Doubling time was calculated from growth curves generated from cell counts of triplicate cultures. 


\section{References Cited in Supplementary Materials}

1. Cline, J. D. Spectrophotometric determination of hydrogen sulfide in natural waters. Limnol. Ocean 14, 454-458 (1969).

2. Ludwig, W., et al. ARB: a software environment for sequence data. Nucleic Acids Res. 32, 1363-1371 (2004)

3. Nercessian, O., Reysenbach, A.-L., Prieur, D. \& Jeanthon, C. Archaeal diversity associated with in situ samplers deployed on hydrothermal vents on the East Pacific Rise $\left(13^{\circ} \mathrm{N}\right)$. Environ. Microbiol 5, $492-502(2003)$.

4. Yu, Y., Lee, C. \& Hwang, S. Analysis of community structures in anaerobic processes using a quantitative real-time PCR method. Water Sci.Technol 52, 85-91 (2005).

5. Beveridge, T. J., Moyles, D. \& Harris R. in Methods for General and Molecular Microbiology (ed. Reddy, C. A., Beveridge, T.J., Breznak, J.A., Snyder, L., Schmidt, T.M, and Marzluf, G.A.) (ASM Press, Washington, D.C., In Press).

6. Huber, J. A., Butterfield, D. A. \& Baross J.A. Temporal changes in archaeal diversity and chemistry in a mid-ocean ridge subseafloor habitat. Appl. Environ. Microbiol 68, 15851594 (2002).

7. Longnecker, K. M.Sc.(Oregon State University, Corvalis, 2001).

8. Kormas, K. A., Tivey, M. K., Von Damm, K. \& Teske, A. Bacterial and archaeal phylotypes associated with distinct mineralogical layers of a white smoker spire from a deep-sea hydrothermal vent site ( $9^{\circ} \mathrm{N}$, East Pacific Rise) Environmental Microbiology. Environ. Microbiol 8, 909-920 (2006).

9. Nercessian, O., et al. Design of 16S rRNA-targeted oligonucleotide probes for detecting cultured and uncultured archaeal lineages in high-temperature environments. . Environ. Microbiol 6, 170-182 (2004).

10. Takai, K. \& Horikoshi, K. Genetic diversity of archaea in deep-sea hydrothermal vent environments. Genetics 152, 1285-1297 (1999).

11. Takai, K., Komatsu, T. Inagari, F. \& Horikoshi, K. Distribution of Archaea in a black smoker chimney structure. Appl. Environ. Microbiol 67, 3618-3629 (2001).

12. Reysenbach, A.-L., Longnecker, K. \& Kirshtein, J. Novel bacterial and archaeal lineages from an in situ growth chamber deployed at a Mid-Atlantic Ridge hydrothermal vent. Appl. Environ. Microbiol 66, 3798-3806 (2000).

13. Hoek, J., Banta, A. B., Hubler, R. F. \& Reysenbach, A.-L. Microbial diversity of a deepsea hydrothermal vent biofilm from Edmond vent field on the Central Indian Ridge. Geobiology 1, 119-127 (2003).

14. Nakagawa, T. et al. Geomicrobiological exploration and characterization of a novel deepsea hydrothermal system at the TOTO caldera in the Mariana Volcanic Arc. Environ Microbiol 8, 37-49 (2006).

15. Inagaki, F. et al. Biogeographical distribution and diversity of microbes in methane hydrate-bearing deep marine sediments on the Pacific Ocean Margin. Proc. Natl. Acad.

Sci U S A. 103, 2815-2820 (2006).

16. Von Damm, K. L. in Physical, Chemical, Biological, and Geological Interactions within Seafloor Hydrothermal Systems (eds. Humphris, S., Lupton, J., Mullineaux, L. \& Zierenberg, R.) 222-247 (American Geophysical Union, Washington, DC, 1995).

17. Tivey, M. K.et al. Characterization of six vent fields within the Lau Basin. Eos. Trans. Am. Geophys. Union 86, T31A-0477 (2005). 
18. Langmuir, C. H., et al. Hydrothermal prospecting and petrological sampling in the Lau Basin: Background data for the integrated study site. Eos Trans. Am. Geophys. Union 85, B13A-0189 (2004).

19. Segerer, A., Langworthy, T. A. \& Stetter, K. O. Thermoplasma acidophilum and Thermoplasma volcanium sp. nov. from solfatara fields. Syst. Appl. Microbiol 10, 161171 (1988).

20. Darland, G., Brock, T.D., Samsonoff, W., Conti, S.F. A thermophilic, acidophilic mycoplasma isolated from a coal refuse pile. Science 170, 1416-1418 (1970).

21. Schleper, C. et al. Picrophilus gen. nov., fam. nov.: a novel aerobic, heterotrophic, thermoacidophilic genus and family comprising Archaea capable of growth around $\mathrm{pH} 0$. J. Bacteriol 177, 7050-7059 (1995). 